\section{Complementary \\ Medicine Research \\ Practice $\mid$ Methods|Perspectives}

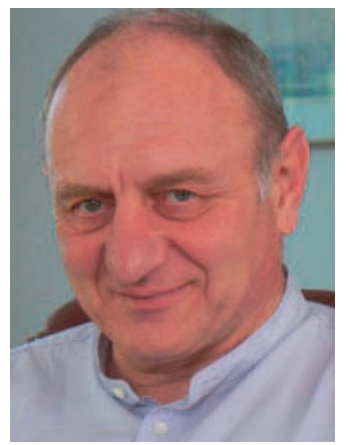

Obituary - Nachruf

Complement Med Res 2017;24:74-75

DOI: $10.1159 / 000475487$

\title{
George Lewith - † March 17, 2017
}

Prof. George Lewith (January 12, 1950 - March 17, 2017), longtime Editorial Board member of our journal, passed away suddenly and unexpectedly while on a skiing holiday with family and friends. We are extremely sad to have lost a pioneering mind, a daring and successful scientist, and a trailblazer of the field of Complementary Medicine (CM) and its research.

George's success lay not in his social background. His father, a Jewish-born engineer originally working for Siemens in Berlin, was imprisoned by the Nazis and eventually survived the holocaust as one of the final inmates of the concentration camp Mauthausen, where he had met George's mother. Both survived the Third Reich. Unfortunately, some family members did not. After having moved to England, it was George's brilliant, eager mind and hard working attitude that earned him best marks in grammar school and an entry into Trinity College Cambridge, where he met the Prince of Wales. He read biochemistry for his undergraduate degree and went to Medical School, eventually becoming a member of the Royal College of Physicians in 1977 and of the Royal College of General Practitioners in 1980. George saw himself first and foremost as a clinician, having worked with and caring for patients since his graduation in 1974, first as registrar in hospitals, later in his own practice. He eventually succeeded in setting up his own private clinic in Harley Street, which he kept running and where he attended to patients until he decided to dedicate his time exclusively to research at an age where others start thinking about taking out an early pension. Others might have been satisfied by earning money in a well-situated private clinic. Not so George: he always wanted to know. Did acupuncture really work, or was it just his impression? Did homeopathy indeed produce specific symptoms in healthy volunteers, or do homeopaths just believe this? What was the component of human contact, and what was the component of specific medication in homeopathy? George's research followed pertinent and clearly focused questions that arose in his clinic, he did not just pick research opportunities that opened up before him. Apart from his clinic in London, he also kept a clinic running in Southampton, and on top of all that a research group which he established with his very specific mix of patience, resilience against drawbacks, and stubbornness in the face of outright opposition. Thus, he finally succeeded in becoming one of the few professors of $\mathrm{CM}$ in the $\mathrm{UK}$, and perhaps worldwide, who was made professor not because he applied for an open position and was chosen. Rather, the sheer magnitude of George's output some 350 peer-reviewed papers that bear his name as author - and the continuous stream of income in terms of research money left the university little choice but to make him professor if it did not want to break its own rules. He was head of a thriving research group in CM in Southampton that was finally integrated into the Department of General Practice, headed by Prof. Paul Little, who is probably one of the best-known researchers in primary care in the UK, if not worldwide. That fact is testimony to the esteem he had achieved over the years. Apart from that, he was a visiting professor at the Universities of Westminster and Bejing.

George was a pioneering mind. He was one of the first researchers to kick-start research in CM when it was still a real fringe topic and a career killer. He could afford this because he had his income from the clinic and did research as his scientific hobby, thus encouraging and mentoring young people as an example and model. He was the founder of one of the first journals in the field that, incidentally, had the same name as was chosen now for the new English-language presentation of our journal. The former namesake, inaugurated by George, later morphed into another journal. In the same sense, George picked up quickly new ideas and transformed them into practicable, workable projects that would also stand a chance of being funded, finished, and published well. Thus, he was also a well-respected colleague who was sought out by others for collaboration in national and international research programs,

\section{KARGER}

\section{() 2017 S. Karger GmbH, Freiburg}

Fax +497614520714 
such as the first truly pan-European research mappings of CM, the CAMbrella project, or the European Healing Study (EUHEALS). He was the first to investigate various modalities of interest, from acupuncture to Alexander technique, spiritual healing to kinesiology, all of which he either had first-hand experience himself with patients with, or from colleagues. His research methods were clearly structured, rigorous, and hence he succeeded in getting papers into mainstream outlets that many others could only dream of. Thus, he was able to build a reputation for himself and his group that allowed him to approach and solicit money from foundations that would have otherwise shunned back from proposals with such topics.

As a consequence, he was a much sought-after mentor and academic teacher. George never had a shortage of highly gifted $\mathrm{PhD}$ students and postdocs, some of whom he sent out to others to gather more experience rather than keeping them to himself. That testified to a generic streak of his personality: he was a really selfless person in the sense that he kept other people's benefit just as high in his inner hierarchy as his own. When he discovered that a career step might not be beneficial for someone, he would advise people not to take it even though it might have benefitted himself. This is a rare virtue in today's academia and makes a truly good mentor.

George was also seminal for various political developments in the field. As one of the founding members of the International Society of Complementary Medicine Research and its second president, it was under his stewardship that the rotating cycle of conferences was built bringing all regions of the world - Europe, the US, Asia - that are important in Complementary Medicine Research into focus. But he would also support the younger movement of Integrative Medicine, that tries to build bridges with conventional medicine and hence is necessarily closer to currently practiced academic medicine, by speaking and presenting at conferences.

George was a relentless hard worker. Those who worked closely with him used to receive e-mails either written personally by him shortly after he got up at 6 am or dictated in his car on his way to work and then typed by his secretary. And before one could respond, the next one written by George or a dictated answer to another e-mail from the day before would pop up. When he was collaborating on a paper or proposal, his turn-around-times were of lightning speed. Sometimes, less than an hour passed until a first draft of a paper or proposal came back with closely-knitted edits and suggestions in comment boxes. With all his work, he still found time for his family, namely his wife Nicola and the 3 children and 3 grand children, whom he loved above all, and all his hobbies, some of which being to tend to his large garden at home, swimming, and walking. George was sportive, being a former rugby coach and player, he kept himself fit through all sort of things, skiing being one of his favorite winter pastimes. It is tragic that it was during a skiing holiday that he passed away. 'Whom the Gods love, they call young' is the gist of an old Greek adage. George was young, in comparison to average periods of life nowadays. Loved by the Gods, he will be missed by us humans, certainly by us. We will keep his mind in our work, his soul in our heart.

Harald Walach and Benno Brinkhaus 